\title{
EFEKTIVITAS PROGRAM GENERASI BERENCANA PUSAT INFORMASI KONSELING (PIK) REMAJA BAGI SISWA SMA NEGERI DI KOTA BANDA ACEH
}

\author{
Intan Liana ${ }^{1}$ \\ ${ }^{1}$ Jurusan Keperawatan Gigi Poltekkes Kemenkes Aceh, Jl. Soekarno Hatta Desa Lagang Kabupaten Aceh Besar \\ *Corresponding Author : intan_liana62@yahoo.com
}

\begin{abstract}
Abstrak
Pemerintah telah mengupayakan program generasi berencana bagi remaja untuk mengendalikan persoalan terkait remaja. Namun, masih terdapat remaja yang berperilaku negatif sex bebas (12,5\%), menonton film porno (90\%) penyalahgunaan napza, dan lain sebagainya. Tujuan penelitian ini adalah mengetahui efektivitas program generasi berencana dalam kelompok pusat informasi konseling remaja bagi siswa kelas 2 SMA Negeri di Kota Banda Aceh, yang dilakukan pada Penelitian ini adalah deskriptif analitik dengan desain Cross-sectional penelitian pada bulan April 2016. Responden adalah peserta PIK-Remaja sebanyak 134 siswa dan yang bukan perserta PIK-Remaja juga sebanyak 134 siswa. Analisis data menggunakan uji T-test Independent. Hasil penelitian membuktikan bahwa ada perbedaan rata-rata pengetahuan remaja tentang kesehatan reproduksi $(p$ value $=0,014)$, sikap remaja $(p$ value $=0,012)$, Perilaku seksual remaja $(p$ value $=$ $0,015)$, dan motivasi remaja ( $p$ value $=0,001)$ antara siswa yang mengikuti PIK-Remaja dengan siswa yang tidak mengikuti PIK-Remaja. Disarankan kepada guru hendaknya memberikan motivasi kepada siswa untuk mengikuti kelompok PIK, dan pihak pemerintah untuk mengevaluasi program ini untuk dikemas dalam bentuk yang sesuai dengan kebutuhan remaja khususnya di Aceh.
\end{abstract}

Kata kunci : motivasi; PIK-remaja; dan perilaku

\section{EFFECTIVENESS OF GENERATION PLANNING PROGRAM IN ADOLESCENT COUNSELING INFORMATION CENTER (PIK) SENIOR HIGH SCHOOL IN THE CITY OF BANDA ACEH}

\begin{abstract}
Abstrack
Goverment has endeavored to plam generation program for teens to control problems related to teenagers. However, there are teenagers who behave negatively free sex (12,5\%), watching porn $(90 \%)$, drug abuse. The purpose of this research is to know the effectiveness of generation planning program in a group of adolescent counseling information center for students of grade 2 senior high school in the city of Banda Aceh Aceh. Cross sectional studi design, the T-test Independent test. Results prove that there is a difference in averege knowledge of adolescents about reproductive health $(\mathrm{P}=0,0014)$, attitude $(\mathrm{P}=0,012)$, behavior $(\mathrm{p}=0,0015)$ and motivation $(\mathrm{P}=0,001)$. Suggested to the teacher should provide motivation for students to follow the group $\mathrm{PIK}$, and the goverment to evaluate the program to be packaged in a form suitable to needs of young people in Aceh.
\end{abstract}

Keyword : generation planning program; behavior; motivation. 


\section{PENDAHULUAN}

Perkembangan globalisasi yang terjadi begitu cepat menimbulkan berbagai dampak positif dan dampak negatif bagi pertumbuhan dan perkembangan remaja. Dampak positif yang ditimbulkan yaitu adanya keterbukaan informasi, dimana setiap remaja dapat mengakses informasi tanpa batas. Sedangkan dampak negatif yang ditimbulkan dari adanya globalisasi perkembangan teknologi dan informasi adalah adanya perilaku yang tidak sehat yang terjadi pada remaja. Perilaku yang tidak sehat merupakan masalah besar yang sangat dekat dengan remaja, diantaranya adalah seks bebas, narkoba dan Acquired Immunodeficiency Syndrome (AIDS) ${ }^{1}$.

Masa remaja sangat erat kaitannya dengan perkembangan psikis pada periode yang dikenal sebagai masa pubertas yang diiringi dengan perkembangan seksual. Kondisi ini menyebabkan remaja menjadi rentan terhadap masalah-masalah perilaku beresiko, seperti melakukan hubungan seks sebelum menikah dan penyalahgunaan napza, yang keduanya dapat membawa resiko terhadap penularan Infeksi Menular Seks (IMS), Human Immunodeficiency Virus (HIV) dan AIDS. Kompleksitas permasalahan remaja tersebut perlu perhatian khusus baik dari pihak pemerintah, Lembaga Swadaya Masyarakat (LSM), masyarakat, maupun keluarga, guna menjamin kualitas generasi mendatang ${ }^{2}$.

Berdasarkan hasil survei perilaku seksual yang beresiko pada remaja oleh Komnas Perlindungan Anak Indonesia (KPAI) tahun 2013 di 33 provinsi menyebutkan bahwa 22,6\% remaja pernah melakukan hubungan seks dan 62,7\% remaja Sekolah Menengah Atas (SMA) tidak perawan. KPAI bekerja sama dengan Lembaga Perlindungan Anak, tahun 2016 menemukan bahwa $97 \%$ pernah menonton pornografi, $93,7 \%$ mengaku sudah tidak perawan dan $21,26 \%$ sudah penah melakukan aborsi. Berdasarkan hasil Riskesdas (2013) jumlah kehamilan pada umur remaja (15-19 tahun) sebanyak 1,97\% dari jumlah remaja di Indonesia. Berdasarkan survei yang dilakukan oleh PKBI Provinsi Aceh, ${ }^{3}$. hasil survei yang menunjukkan bahwa $90 \%$ pernah mengakses media pornografi, $40 \%$ mengaku pernah petting atau menyentuh organ intim pasangannya. Dan 12,5\% pernah melakukan hubungan seks bebas. Hal ini mengindikasikan/ menunjukkan adanya perubahan perilaku remaja di Aceh yang semakin mengkhawatirkan, baik pola pergaulan maupun pergeseran moral. Hal tersebut terjadi karena banyak remaja yang terlibat dalam mengonsumsi zat-zat yang dapat membahayakan kesehatan seperti narkoba. Menurut hasil 
penelitian Kepolisian dan BNN tahun 2012 menemukan bahwa terdapat 3,77\% tersangka narkoba adalah siswa SMA. Pada tahun 2013, angka tersebut mengalami peningkatan menjadi 17,01\% ${ }^{4}$.

Menurut hasil menelusuran data awal dari Dinas Pendidikan Kota Banda Aceh tahun 2016, jumlah sekolah SMA Negeri di Kota Banda Aceh yaitu 16 sekolah dengan jumlah siswa sebanyak 7.463 siswa atau sekitar 18,06 \% sedangkan data dari BKKBN Kota Banda Aceh (2015), bahwa Jumlah kelompok PIK-Remaja di tingkat SMA Negeri yaitu sebanyak 14 kelompok dari 16 sekolah SMA Negeri Kota Banda Aceh dan siswa yang mengikuti atau yang menjadi anggota PIK-Remaja sebanyak 254 siswa atau sekitar 3,5 \% dari seluruh jumlah siswa SMA Negeri yang ada kelompok PIK-Remaja. Berdasarkan hasil Survei data awal dari salah satu petugas bidang PIK-Remaja di BKKBN Provinsi Aceh (2016), mengatakan bahwa untuk tercapainya tujuan dari program Generasi Berencana, BKKBN melakukan beberapa kegiatan terhadap kelompok PIK-R, yaitu dengan melakukan sosialisasi, orientasi dan juga memberikan pelatihan-pelatihan untuk siswa yang mengikuti kelompok PIK-R di sekolah. Pihak BKKBN melakukan semua kegiatan tersebut agar program Generasi Berencana dapat efektif. Berdasarkan latar belakang diatas, maka tujuan penelitian ini adalah untuk mengetahui apakah ada perbedaan pengetahuan, sikap remaja, perilaku seksual dan motivasi remaja yang mengikuti dengan yang tidak PIK-Remaja, sehingga peneliti dapat mengetahui efektivitas program generasi berencana dalam kelompok pusat informasi konseling remaja bagi siswa SMA Negeri di kota Banda Aceh. Penelitian diharapkan dapat bermanfaat bagi remaja SMA yang ada di Kota Banda Aceh untuk mengikuti program pusat informasi konseling remaja (PIK-R) di sekolah, serta memberikan masukan kepada pihak BKKBN dalam mengevaluasi program konseling bagi siswa.

\section{METODE}

Jenis penelitian ini bersifat deskriptif analitik dengan menggunakan desain cross sectional. Populasi dalam penelitian ini adalah seluruh siswa SMA Negeri kelas XI yang mengikuti dan yang tidak mengikuti PIK-Remaja di seluruh SMA Kota Banda Aceh yang berjumlah 14 SMA dengan jumlah seluruh siswa SMA kelas XI yaitu 2.592 siswa, yang mengikuti PIK-Remaja 254 (9,7\%), dan yang tidak mengikuti PIK-Remaja 2338 (90\%).

Penentuan jumlah sampel dilakukan dengan menggunakan rumus Lameshow sebagai berikut :

$\mathrm{n}=\frac{\mathrm{z}_{1-\mathrm{k} / 2}^{2}\left[\mathrm{P}_{1}\left(1-\mathrm{P}_{1}\right)+\mathrm{P}_{2}\left(1-\mathrm{P}_{2}\right)\right]}{\mathrm{d}^{2}}$ 
Keterangan :

$\mathrm{n} \quad=$ Besar sampel

$z_{1-c / 2}^{2}=$ Statistik $Z$ (misalnya $=1.96$ untuk $\alpha=0,05$ )

$P_{1} \quad=$ Perkiraan proporsi pada populasi 1

$\mathrm{P}_{2} \quad=$ Perkiraan proporsi pada populasi 2

$\mathrm{d}=$ Presisi absolut yang diinginkan

Jumlah sampel sebanyak 67 siswa. Namun, pada penelitian ini jumlah sampel yang diambil adalah 2 kali jumlah sampel minimal, dengan perbandingan sampel yang akan diambil 2 kali dari perhitungan sampel minimum, dengan perbandingan 1:1 diperoleh sampel sebesar 268 siswa. menggunakan teknik sampel secara kelompok atau gugus (Cluster Random sampling). Penelitian ini dilakukan di SMA Negeri 2, SMA Negeri 7, dan SMA Negeri 8, SMA Negeri 10, SMA Negeri 11, dan SMA Negeri 12 Kota Banda Aceh. Penelitian ini telah dilaksanakan melalui hasil penyebaran angket kepada responden. Data yang sudah didapat selanjutnya diolah secara komputerisasi dengan mengunakan program STATA 13.0. Dalam menganalisi data penelitian ini menggunakan tes normalitas data yaitu menggunakan Shapiro-wilk normality test, untuk mengetahui apakah data berdistribusi normal, apabila datanya berdistribusi normal maka peneliti dapat melanjutkan melakukan analisis data dengan menggunakan uji T-test Independen atau disebut juga uji $\mathrm{T}$ tidak berpasangan yaitu untuk melihat perbedaan rata-rata dua kelompok, antara kelompok yang mengikuti PIK-Remaja dengan yang tidak mengikuti PIK-Remaja.

\section{HASIL PENELITIAN}

Penelitian ini dilakukan pada 134 siswa yang mengikuti PIK dan 134 siswa yang tidak mengikuti PIK. Hasil penelitian diketahui bahwa responden dengan jenis kelamin laki-laki sebanyak $31,72 \%$ dan jenis kelamin perempuan sebanyak $68,28 \%$. Remaja yang tidak mengikuti kegiatan PIK remaja memiliki perilaku seksual ringan $45,52 \%$, perilaku seksual berat $17,91 \%$ dan yang tidak memiliki perilaku seksual 36,57\%.

Sementara remaja yang mengikuti kegiatan PIK-Remaja adalah seperti gambar berikut : 


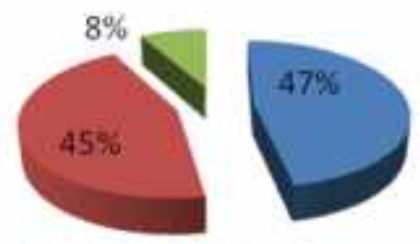

Tidak ada perilaku seksual wiseksual ringan wseksual berat

Gambar 1. Perilaku Seksual yang mengikuti Program PIKRemaja Di Banda Aceh

Tabel 1. Perbedaan pengetahuan remaja yang mengikuti dengan yang tidak pengikuti PIK-Remaja bagi siswa SMA Negeri di Kota Banda Aceh

\begin{tabular}{lccccccc}
\hline Pengetahuan remaja & $\mathrm{n}$ & mean & SD & SE & Min Max & P value \\
\hline Mengikuti PIK-R & 134 & 79,56 & 15,356 & 1,326 & 46 & 100 & \\
& & & & & & & 0,014 \\
Tidak mengikuti PIK-R & & 134 & 75,03 & 14,661 & 1,266 & 46 & 100 \\
& & & & & & & \\
\hline
\end{tabular}

Tabel 2. Perbedaan sikap remaja yang mengikuti dengan yang tidak mengikuti PIKremaja bagi siswa SMA Negeri di Kota Banda Aceh

\begin{tabular}{lcccccccc}
\hline Sikap remaja & $\mathrm{n}$ & mean & SD & SE & Min & Max & P value \\
\hline Mengikuti PIK-R & 134 & 10,09 & 1,584 & 0,136 & 7 & 12 & & \\
& & & & & & & 0,012 & Tidak \\
mengikuti PIK-R & 134 & 9,61 & 1,584 & 0,136 & 46 & 12 & \\
\hline
\end{tabular}


Tabel 3. Perbedaan perilaku seksual remaja yang mengikuti dengan yang tidak mengikuti PIK-remaja bagi siswa SMA Negeri di Kota Banda Aceh

\begin{tabular}{lccccccc}
\hline Perilaku remaja & $\mathrm{n}$ & mean & SD & SE & Min & Max & P value \\
\hline Mengikuti PIK-R & 134 & 2,38 & 0,636 & 0,05 & 1 & 3 & \\
Tidak mengikuti PIK-R & & 134 & 2,18 & 0,716 & 0,061 & 1 & 3 \\
\hline
\end{tabular}

Tabel 4. Motivasi perbedaan motivasi remaja yang mengikuti dengan yang tidak mengikuti PIK-remaja bagi siswa SMA Negeri di Kota Banda Aceh

\begin{tabular}{lccccccc}
\hline Motivasi remaja & $\mathrm{n}$ & mean & $\mathrm{SD}$ & $\mathrm{SE}$ & Min & Max & P value \\
\hline Mengikuti PIK-R & 134 & 5,29 & 0,715 & 0,061 & 3 & 6 & \\
& & & & & & & 0,001 \\
Tidak mengikuti PIK-R & & 134 & 3,93 & 0,796 & 0,068 & 3 & 5 \\
\hline
\end{tabular}

\section{PEMBAHASAN}

Hasil penelitian menunjukkan bahwa nilai rata-rata pengetahuan remaja yang mengikuti PIK-Remaja adalah 79,56 dengan standar deviasi 15,356 sedangkan nilai rata-rata pengetahuan remaja yang tidak mengikuti PIK-Remaja adalah 75,03 dengan standar deviasi 14,661. Dari uji statistik di dapatkan nilai $P$ value $=0,014$. maka terdapat perbedaan yang bermakna tingkat pengetahuan remaja yang mengikuti dengan yang tidak mengikuti PIK-Remaja. Rata-rata Pengetahuan siswa yang mengikuti PIK-Remaja lebih tinggi dibandingkan dengan yang tidak mengikuti PIK-Remaja karena yang mengikuti PIK-Remaja lebih banyak mendapatkan informasi dengan mengikuti sosialisasi dan pelatihan yang berkaitan dengan kesehatan reproduksi remaja, sedangkan yang tidak mengikuti PIK-Remaja mereka hanya mempelajari ketika belajar mata pelajaran biologi dan mempelajari satu atau dua kali pertemuan saja dan juga dari media sosial, berbeda dengan yang mengikuti PIK-Remaja selain di sekolah mereka juga mengikuti seminar 
tentang kesehatan reproduksi yang dilaksanakan diluar sekolah. Namun, keikutsertaan remaja dalam kegiatan tersebut, masih memiliki perilaku negatif, seperti terlihat pada gambar 1, 45\% remaja berperilaku seksual ringan. Adanya pengaruh lingkungan dan terpapar dengan tehnologi, yang kemungkinan berdampak pada faktor sosial, budaya, eksploitasi seksual, dan masyarakatnya. ${ }^{5}$

Dalam kelompok pusat informasi konseling remaja, siswa diajarkan tentang seksualitas yang meliputi tumbuh kembang remaja, alat, sistem dan proses reproduksi, konsekuensi hubungan sex pra nikah, penyakit menular sex (PMS), dan juga tentang Napza. Sehingga siswa yang mengikuti PIK-Remaja pengetahuan tentang kesehatan reproduksi lebih baik dibandingkan dengan yang tidak ikut PIK-Remaja. Pengetahuan remaja tentang kesehatan reproduksi menjadi bekal remaja dalam berperilaku sehat dan bertanggung jawab, namun tidak semua remaja memperoleh informasi yang cukup dan benar tentang kesehatan reproduksi. Keterbatasan pengetahuan dan pemahaman ini membawa remaja ke arah perilaku berisiko. Dalam hal inilah bagi para ahli dalam bidang ini memandang perlu akan adanya pengertian, bimbingan, dan dukungan dari lingkungan di sekitarnya agar dalam system perubahan tersebut terjadi pertumbuhan dan perkembangan yang sehat sedemikian rupa sehingga kelak remaja menjadi manusia dewasa yang sehat secara jasmani, rohani, dan sosial. ${ }^{6}$

Terdapat hubungan bermakna antara pemanfaatan PIK-Remaja dengan pengetahuan $\mathrm{OR}=5.20(95 \%$ CI 2,07-13,06) dengan sikap $\mathrm{OR}=3,76(95 \% 1,86-7,60)$, perilaku $\mathrm{OR}=3,16$ (95\%1,36 - 7,32). Pemanfaatan PIK-Remaka sebesar 16\% hambatan pemanfaatan PIK-Remaja, adanya rasa malu, waktu layanan, petugas kurang komunikatif, ruang tidak nyaman. Semakin tinggi pengetahuan dan sikap positif terhadap pranikah maka peluang untuk memanfaatkan PIKRemaja semakin besar ${ }^{7}$

Hasil penelitian menunjukkan bahwa nilai rata-rata sikap siswa yang mengikuti PIKRemaja adalah 10,09 dengan standar deviasi 1,584 sedangkan nilai rata-rata sikap remaja yang tidak mengikuti PIK-Remaja adalah 9,61 dengan standar deviasi 1,584. Dari uji statistik di dapatkan nilai $P$ value $=0,012$ pada taraf signifikan $\alpha=0,05$. Karena $P$ value $<0,05$ maka terdapat perbedaan yang bermakna sikap remaja yang mengikuti dengan yang tidak mengikuti PIK-Remaja. Salah satu faktor yang mempengaruhi sikap adalah Lembaga Pendidikan dan Lembaga Agama dimana konsep moral dan ajaran dari lembaga pendidikan dan lembaga agama sangat menentukan sistem kepercayaan tidaklah mengherankan jika kalau pada gilirannya konsep 
tersebut mempengaruhi sikap. Sikap siswa yang mengikuti PIK-Remaja dengan yang tidak mengikuti PIK-Remaja ada perbedaan, karena siswa yang mengikuti PIK-Remaja pengetahuannya labih baik dibandingkan dengan yang tidak ikut PIK-Remaja, sehingga sikap siswa berbeda. Semakin positif sikap remaja terhadap perilaku seksual maka semakin besar intensinya untuk tidak melakukan perilaku seksual secara bebas dan menjaga kesehatan reproduksinya, sedangkan remaja yang memiliki sikap yang negatif terhadap perilaku seksual akan semakin besar intensinya untuk melakukan perilaku seksual ${ }^{8}$.

Hasil uji penelitian menunjukkan bahwa nilai rata-rata perilaku remaja yang mengikuti PIK-Remaja adalah 2,38 dengan standar deviasi 0,636 sedangkan nilai rata-rata perilaku remaja yang tidak mengikuti PIK-Remaja adalah 2,18 dengan standar deviasi 0,716. Dari uji statistik di dapatkan nilai $P$ value $=0,015$ pada taraf signifikan $\alpha=0,05$. Karena $P$ value $<0,05$ maka terdapat perbedaan yang bermakna perilaku seksual remaja yang mengikuti dengan yang tidak mengikuti PIK-Remaja. Hasil penelitian didapatkan ada perbedaan perilaku seksual remaja yang mengikuti PIK-Remaja dengan yang tidak mengikuti PIK-Remaja, disebabkan karena siswa yang ikut PIK-Remaja pengetahuan tentang kesehatan reproduksi lebih baik dibandingkan dengan tidak ikut PIK-Remaja, karena mereka sering mengikuti sosialisasi di sekolah. Sehingga mereka tahu apa dampak dari perbuatan yang akan mereka lakukan, dan dapat mencegah dirinya dari perilaku yang merugikan masa depannya.

Perilaku seksual adalah segala bentuk perilaku yang didorong oleh hasrat seksual, baik dengan lawan jenis maupun dengan sesama jenis. Bentuk perilaku seksual, mulai dari bergandengan tangan (memegang lengan pasangan), berpelukan (seperti merengkuh bahu, merengkuh pinggang), bercumbu (seperti cium pipi, cium kening, cium bibir), meraba bagian tubuh yang sensitif, menggesek-gesekkan alat kelamin sampai dengan memasukkan alat kelamin. Perilaku seksual merupakan perilaku yang bertujuan untuk menarik perhatian lawan Jenis ${ }^{9,10}$ Penyimpangan terhadap seksual pada remaja dikarenakan terlalu dominannya pengaruh lingkungan dan media massa dalam menyebarkan informasi seksual bebas, sementara petugas kesehatan dan sekolah kurang membekali pengetahuan tentang seksual yang sebanding dengan apa yang diperoleh melalui internet. Pengaruh informasi tidak benar mudah didapatkan remaja yang dapat memberikan pengaruh buruk bila tidak diimbangi dengan informasi yang benar dan tepat tentang kesehatan reproduksi, maka remaja dengan mudah mengeksploitasi dan 
menyalurkan gejolak jiwa dalam dirinya sehingga mudah terjerumus dalam permasalahan seksualitasnya ${ }^{10}$.

Dari hasil pengamatan peneliti bahwa masih banyak beberapa siswa dan siswi yang belum mengerti dan memahami pentingnya kesehatan reproduksi. Perilaku siswa dan siswi juga semakin mengkhawatirkan termasuk dalam hal perilaku berpacaran yang semakin bebas dan menjurus ke aktivitas seksual yang berat. Sehingga perlu untuk mereka mendapatkan informasi yang lebih efektif dengan mengikuti kelompok PIK-Remaja. Bimbingan dan pengawasan perlu diberikan selama siswa melaksanakan atau mengikuti pembelajaran kesehatan reproduksi agar siswa termotivasi untuk mempelajarinya dengan sungguh-sungguh, sehingga siswa memperoleh informasi kesehatan reproduksi yang benar dan tepat. Motivasi yang berhubungan dengan kebutuhan, motif dan tujuan sangat mempengaruhi kegiatan dan hasil belajar. Motivasi penting bagi proses belajar karena menggerakkan organisme, mengarahkan tindakan, serta memiliki tujuan belajar yang paling berguna bagi kehidupan individu. Semakin tinggi motivasi siswa belajar tentang kesehatan reproduksi semakin banyak informasi atau ilmu yang didapatkan sehingga siswa dapat tercegah dari perilaku kenakalan remaja. Hasil penelitian menunjukkan bahwa nilai rata-rata motivasi remaja yang mengikuti PIK-Remaja adalah 5,29 dengan standar deviasi 0,715 sedangkan nilai rata-rata motivasi remaja yang tidak mengikuti PIK-Remaja adalah 3,93 dengan standar deviasi 0,796. Dari uji statistik di dapatkan nilai $P$ value $=0,001$, dimana terdapat perbedaan yang bermakna motivasi remaja yang mengikuti dengan yang tidak mengikuti PIK-Remaja.

Perilaku ingin mencoba-coba merupakan hal penting bagi kesehatan reproduksi remaja. Perilaku ingin mencoba hal yang baru jika didorong oleh seksual dapat membawa remaja masuk pada hubungan seks pranikah dengan segala akibatnya. Beberapa permasalahan prioritas terkait perilaku remaja yang ingin mencoba hal baru, yaitu kehamilan yang tidak dikehendaki akan menjurus pada aborsi yang tidak aman dan komplikasi, kehamilan dan persalinan usia muda akan menambah resiko kesakitan dan kematian ibu dan bayi (2-4 kali lebih tinggi dari masa usia subur), penularan penyakit kelamin, termasuk HIV/AIDS, ketergantungan narkoba, psikotropika, dan zat adiktif dan tindak kekerasan seksual, seperti pemerkosaan, pelecehan, dan transaksi seks komersial. Dari segi kesehatan reproduksi, perilaku ingin mencoba-coba dalam bidang seks merupakan hal yang sangat rawan, karena akan membawa akibat yang sangat buruk dan merugikan masa depan remaja, khususnya remaja wanita ${ }^{6}$. 
Motivasi seseorang dapat mempengaruhi perilaku atau dorongan oleh kepentingan untuk memenuhi atau memuaskan diri terhadap kebutuhan yang ada pada diri individu. Motivasi tidak hanya bermula dari kebutuhan individu saja, tetapi juga karena faktor belajar. Sekolah merupakan sebagai instusi pendidikan mempunyai kesempatan yang luas untuk menjadi tempat penyebaran informasi dengan memanfaatkan fasilitas kelompok yang menjalankan suatu program kesehatan disekolah, sehingga dapat meningkatkan pengetahuan, sikap, motivasi dan perilaku para remaja yang berkaitan dengan pencegahan dari risiko (seksual, HIV/AIDS dan Napza) ${ }^{11}$. Motivasi ini akan lebih baik dengan adanya dukungan pemerintah, yang memadukan antara kebijakan kesehatan reproduksi paradigma baru ditingkat global, nasional dan daerah.

Petugas kesehatan juga memiliki peran dalam keberlangsungan pelayanan kesehatan bagi remaja. Petugas dapat memberikan motivasi mereka untuk menggali informasi sebanyak mungkin dari kliennya, sikap proaktif petugas dalam melakukan anamnesis dapat meningkatkan pelayanan kesehatan menjadi lebih berkualitas dan sesuai dengan kebutuhan klien ${ }^{12}$. Perilaku remaja dalam memanfaatkan pelayanan kesehatan reproduksi juga tergantung pada kebiasaan atau budaya setempat, pengaruh keluarga, teman sebaya, dan kemudahan akses dalam mendapat informasi kesehatan bagi remaja ${ }^{12}$. Kehidupan masyarakat Aceh, masih ada beberapa diantara orang tua masih kesulitan untuk menyampaikan informasi tentang pendidikan seks pada remaja, dan para orang tua hanya mengandalkan kelompok belajar agama atau mengaji untuk mendapatkan informasi tentang pendidikan seks pada remaja. Kecenderungan orang tua yang beda cara pandang dan cara mengkomunikasikan pada remaja. Sementara, remaja itu sangat membutuhkan orang yang memberikan pelayanan pendidikan seks adalah dari kalangan sebaya agar mudah bagi remaja untuk menyampaikan permasalahan yang dialaminya, akan tetapi bukan yang hanya mampu mendengar, dan mengajukan beberapa pertanyaan saja, tetapi dapat memberikan solusi ${ }^{11}$.

\section{KESIMPULAN DAN SARAN}

Setelah dilakukan penelitian, dapat disimpulkan sebagai berikut :

1. Ada perbedaan tingkat pengetahuan siswa yang mengikuti PIK-Remaja dengan yang tidak mengikuti PIK-Remaja di SMA Negeri Kota banda Aceh ( $p$ value 0,014)

2. Ada perbedaan sikap remaja yang mengikuti PIK-Remaja dengan yang tidak mengikuti PIKRemaja di SMA Negeri Kota banda Aceh( $p$ value 0,012) 
3. Ada perbedaan perilaku seksual remaja yang mengikuti PIK-Remaja dengan yang tidak mengikuti PIK-Remaja di SMA Negeri Kota banda Aceh ( $p$ value 0,015).

4. Ada perbedaan motivasi yang mengikuti PIK-Remaja dengan yang tidak mengikuti PIKRemaja di SMA Negeri Kota banda Aceh ( $p$ value 0,001)

Berdasarkan kesimpulan yang telah disebutkan di atas, maka dapat direkomendasikan :

1. Diharapkan kepada petugas BKKBN khususnya bagian pengelola PIK-Remaja, dapat memberikan motivasi dan senantiasa memberikan sosialisasi kepada siswa dan siswi di sekolah dengan tema yang lebih menarik dan sesuai dengan kebutuhan siswa akan informasi tentang kesehatan reproduktif.

2. Diharapkan kepada Guru agar lebih memberikan motivasi kepada siswa-siswi yang belum mengikuti PIK-Remaja, karena masih banyak remaja yang belum mengikuti PIK-Remaja guna untuk mendapat informasi yang cukup dan benar sesuai kebutuhan remaja,

3. Perlu dilakukan advokasi bagi para penentu kebijakan daerah, dalam memfasilitasi program PIK-Remaja kearah yang lebih baik dengan melibatkan orang tua dan lintas sektor.

\section{UCAPAN TERIMA KASIH}

Penulis mengucapkan terima kasih yang sebesar-besarnya kepada pihak PPSDM yang telah memfasilitasi dalam penyusunan artikel ilmiah, BKKBN Kota Banda Aceh dan mahasiswa Fakultas Kesehatan Masyarakat yang telah membantu dalam pengumpulan data. Serta semua pihak yang telah membantu terlaksananya penelitian ini.

\section{REFERENSI}

1. Wirdhana, Indra, Kurikulum Diklat Teknis GENRE, Jakarta: BKKBN, 2013.

2. BKKBN, 2011. Generasi Berencana Yang Sehat dan Berakhlak Mulia, Jakarta: 2011.

3. Memprihatinkan, Sisi Gelap Kehidupan ABG di Aceh, Banda Aceh Serambi Indonesia,: Kompas.com, 2014.

4. BNN RI, Analisa Data Pencegahan Dan Pemberantasan Penyalahgunaan Dan Peredapan Gelap Narkoba, Jakarta: 2014.

5. Jesica L. Moris, Hamid Rushwan. adolescent sexual and reproduktive health : the global challengess., International journal of gynecology and obstetric 131 (2015) 540-542.

6. Kumalasari, Intan, dkk., Kesehatan Reproduksi untuk Mahasiswa Kebidanan dan Keperawatan, Jakarta selatan : salemba medika, 2012.

7. Yeni Lucin, Pengetahuan, Sikap dan Perilaku tentang Seks Pranikah Terhadap pemanfaatan pusat informasi konseling kesheatan reproduksi remaja pada remaja di kota Palangkaraya, Tesis. UGM 2012. 
8. Soetjiningsih, Tumbuh kembang remaja dan permasalahannya, Jakarta: Sagung Seto, 2007.

9. Sarwono, W.S., Psikologi Remaja, Jakarta: PT Rajawali Press, 2011.

10. Adnani, Hariza, Motivasi Belajar dan sumber Informasi Tentang Kesehatan Kesehatan Reproduksi dengan Perilaku seksual Remaja di SMUN 2 Banguntapan Bantul, Jurnal Kesehatan, Yogyakarta : Surya Medika, 2007.

11. Ayu tambe, et al., Understanding sexual and reproduktive health need of adolescent : evidence from a formative evaluation in Wakiso district, Uganda. Reproduktive health (2015) 12;35. DOI 10.1186/s 12978-015-0026-7 Biomed central.

12. Zaini Fatoni, dkk., Implemantasi Kebijakan Kesehatan Reproduksi di Indonesia : sebelum dan sesudah reformasi., Jurnal Kependudukan Indonesia. Vol.10 No. 1 Juni 2015. 65-74. E-ISSN : 2502-8537 (Online). 